\title{
Kinolon ilişkili nadir bir komplikasyon: Uzun QT sendromu
}

\section{A rare quinolone-associated complication: Long QT sydrome}

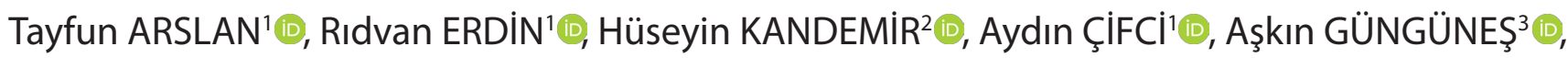 \\ Selim YALÇIN 4 , Taner SARAK ${ }^{2}$, Mehmet KABALCI ${ }^{\square}$
}

${ }^{1}$ Kırıkkale Üniversitesi Tıp Fakültesi, İç Hastalıkları ABD, Kırıkkale/TÜRKIYE

${ }^{2}$ Kırıkkale Üniversitesi Tıp Fakültesi Kardiyoloji ABD, Kırıkkale/TÜRKIYE

${ }^{3}$ Kırıkkale Üniversitesi Tıp Fakültesi İç Hastalıkları ABD, Endokrinoloji BD, Kırıkkale/TÜRKiYE

${ }^{4}$ Kırıkkale Üniversitesi Tıp Fakültesi İç Hastalıkları ABD, Tıbbi Onkoloji BD, Kırıkkale/TÜRKIYE

${ }^{5}$ Kırıkkale Üniversitesi Tıp Fakültesi Kalp ve Damar Cerrahisi ABD, Kırıkkale/TÜRKIYE

\section{öz}

Enfekte diyabetik ayak ülserlerinin tedavisinde antibiyotikler sık kullanılan tedavi ajanları arasında yer almaktadır. Ancak antibiyotiklere bağı bazen hayatı tehdit edebilecek boyutta ciddi yan etkiler görülebilir. Bu yazıda enfekte diyabetik ayak ülseri nedeniyle kinolon grubu antibiyotik tedavisi başlanan bir hastada bu tedaviyi takiben gelişen uzun QT sendromu ve devamında kardiyopulmoner arrest gelişen ve defibrilasyon tedavisi ile reanimasyonu sağlanan oldukça nadir bir vaka tartışılarak nadir görülen komplikasyon üzerine dikkat çekmeyi amaçladık.

Anahtar kelimeler: uzun QT sendromu, antibiyotik, kinolon

\section{ABSTRACT}

In the treatment of infected diabetic foot ulcers, antibiotics are frequently used as treatment agents. However, serious adverse effects may be seen on antibiotics, which can sometimes be life-threatening. In this article, we aimed to draw attention to a rare complication in a patientwhowastreatedwithquinoloneantibioticsduetoinfecteddiabeticfootulcer, a rare long QT syndrome following this treatment, subsequent cardiopulmonary arrest and reanimation with defibrillation therapy.

Keywords: long QT syndrome; antibiotic; quinolone

Sorumlu Yazara: Tayfun Arslan, Kırıkkale Üniversitesi Tıp Fakültesi, İç Hastalıkları ABD, Kırıkkale/TÜRKiYE E-posta: tayfunarslan066@hotmail.com ORCID: 0000-0002-4552-7768 


\section{Giriş}

Uzun QTsendromları EKG'de uzamış QT mesafesi ile karakterize olan kardiyak repolarizasyon bozukluklarıdır. Doğumsal veya edinsel nedenlere bağlı olarak ortaya çıkabilmektedir. QT değerinin kalp hızına göre düzeltilmiş değeri için (QTc) 350420 msn arası değerler normal, 420-440 msn arasındaki değerler sınırda, 440 msn üzerindeki değerler ise yüksek olarak kabul edilmektedir [7]. EKG'de uzamış QT aralığı ve T dalgası değişiklikleri ile özellikle sempatik aktivitenin arttığı egzersiz veya emosyonel durumlarda yaşamı tehdit eden torsade de pointes(TdP) tipi ventriküler taşikardiler sonucu, senkop atakları ve/veya ani kardiyak ölüm karakteristik bulgulardır[1-3]. Uzun QT sendromunun edinsel tipi doğumsal tipinden daha sıktır, kadınlarda daha sık görülür ve tipik olarak QT mesafesini uzatan elektrolit bozukluklarıveilaçlarla tedavinin bir komplikasyonu olarak ortaya çıkar [4]. QT aralığının uzaması kinidin, sotalol, amiodaron, prokainamid gibi antiaritmik ilaçlar ile birlikte görülebilmekle beraber antiaritmik kardiyak ilaçlar dışında diğer grup ilaçlarda bu duruma neden olabilir[6]. Edinsel uzun QT sendromunun nedeni tam olarak bilinmemektedir. Bir hipoteze göre, iyon kanalları ya da diğer genlerdeki subklinik mutasyonlar uygun ortamlarda hastayı aşırı QT uzamasına yatkın hale getirebilir [5]. Bu yazıda diyabetik ayak enfeksiyonu nedeni ile florokinolon grubu bir antibiyotik olan moksifloksasin başlanan ve takibinde edinsel uzun QT sendromuna bağlı kardiyak arrest gelişen bir olgu sunulmuştur.

Literatürde antibiyotik alımından birkaç gün sonra QTC mesafesi uzayan vakalar bildirilmekle birlikte tek doz sonrası görüldüğüne dair bir makale görülmedi. Bu yönüyle de bu vaka sunulmaya değer görülmüştür.

\section{Olgu}

İki yıldır bilinen tip 2 diabetes mellitus tanısı olan ve oral antidiyabetik kullanan 65 yaşında kadın hasta, kan şekeri regülasyon bozukluğu ve sağ ayakta diyabetik ayak ülseri ile başvurdu. Hastanın fizik muayenesinde ayak bileğine kadar uzanankızarıklık, ödem, hassasiyet, Isı artışı ve anaerobik koku mevcuttu. Ayak falankslarında lokalize nekroz bulunan bu yara Wagner evre 4 olarak değerlendirildi. Laboratuvar değerlerinde CRP: $170 \mathrm{mg} / \mathrm{l}(0,15-5 \mathrm{mg} / \mathrm{l})$, eritrosit sedimentasyon hızı: $84 \mathrm{~mm} /$ saat (0-20mm/saat), beyaz küre: 27.130 /mm3(440011300 /mm3),trombosit: 434.000/mm3(150000-500000 / mm3),hemoglobin: 10,2g/dl (10-18 g/dl), kalsiyum: 8,09 mg/ dl (düzeltilmiş kalsiyum: 8,88 mg/dl)(8,8-10,2 mg/dl), potasyum: 3,96 mmol/l (3,5-5,1 mmol/l), magnezyum: 2,10 $\mathrm{mg} / \mathrm{dl}$ (1,9-2,55 mg/dl), albumin: 3,01g/dl (3,5-5,2 g/dl) idi ve diğer laboratuvar değerlerinde belirgin bozukluk yoktu. Hastanın başvuru anındaki EKG'si (Resim 1) normal sinüzal ritm idi. Has- taya diyabetik ayak enfeksiyonu için enfeksiyon hastalıklarının önerisiyle moksifloksasin 400 mg 1x1/gün ile birlikte piperasilin-tazobaktam 3x4,5 gr/gün başlandı. Tedavisinin ikinci günü baş dönmesi,bulantışikayetleri oldu, ardından hasta mönitorize edildi, çekilen EKG'sinde (Resim 2) kalp hızı dakikada 64 atım, Bazett formülüne göre düzeltilmiş QT mesafesinin 496 msn ile uzamışolduğu tespit edildi. Kardiyoloji konsültasyonusonucu hastada bu durumun primer kardiyak bir problemden ziyade kullanmış olduğu kinolon grubu antibiyotik (moksifloksasin) tedavisine bağlı olduğu düşünüldü ve bu antibiyotiği kesildi. Ancakbu sırada genel durumu bozulmuş olan hastada yaklaşık 1 saat sonra kardiyopulmoner arrest gelişti. Kardiyopulmoner resusitasyona başlanıp entübe edilen hastada kardiyak ritm olarak ventiküler fibrilasyon gözlendi ve150 joule ile defibrilasyon uygulandı. Normal sinüs ritmine dönenhasta yoğun bakıma alınıp mekanik ventilatöre bağlandı. Enfeksiyon hastalıklarının önerisi ile kesilmiş olan moksifloksasin yerine tedavisine teikoplanin $400 \mathrm{mg} \mathrm{1x1/gün} \mathrm{eklendi.} \mathrm{Genel} \mathrm{durumu} \mathrm{gün}$ içinde hızla düzeldi ve ertesi gün ekstübe edildi, birkaç günlük yoğun bakımda yakın takibin ardından genel durumu daha da düzelen hasta servise alındı. Sonrasında ayağındaki enfeksiyon gerilemeyen hastaya ortopedi bölümünce sağ bacak diz altı amputasyon uygulandı. Hastanın takiplerinde genel durumu düzeldi, tedavisi düzenlenen hasta önerilerle taburcu edildi.

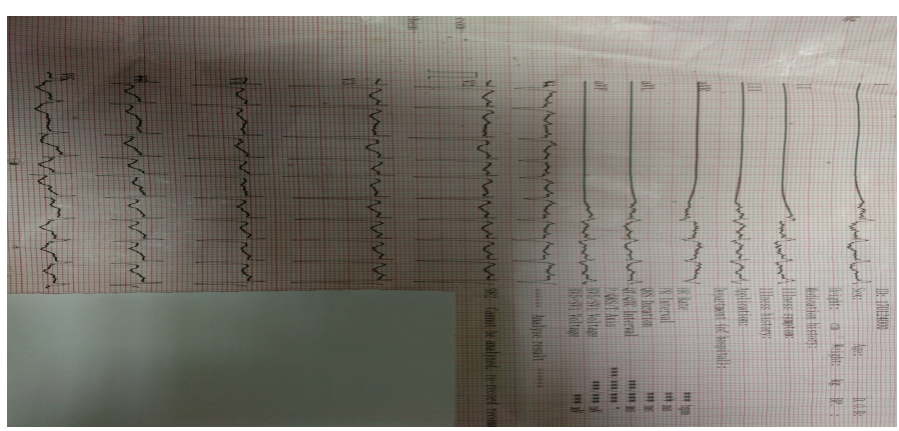

Resim 1: Başvuru anındaki EKG.

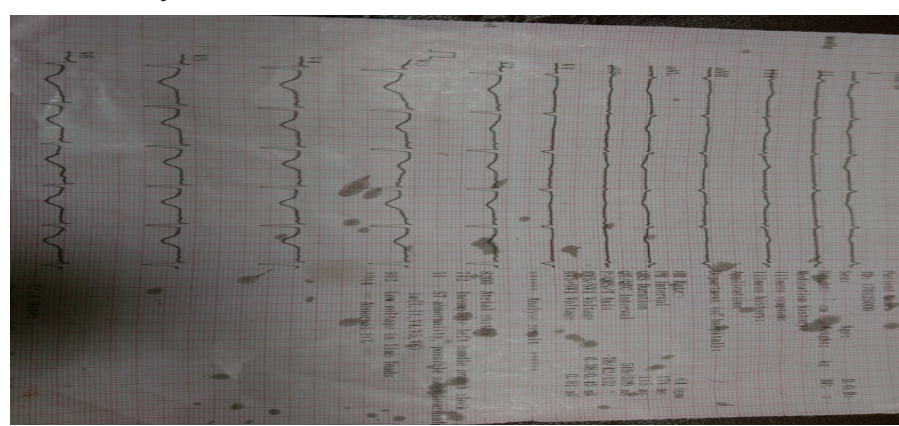

Resim2: QT mesafesi uzamış EKG.

Çalışma için yerel etik kurul onayı alındı. Hasta onam formları imzalatıldı.

\section{Tartışma}

Yeni nesil fluorokinolonlar halen kullanılmakta olan en aktif ve geniş spektrumlu oral antibakteriyelleri içermektedir [12-13]. 
Florokinolon grubu antibiyotikler doz bağımlı olarak gecikmiş düzenleyici potasyum akımının hızı bileşenini bloke ederler ve bu etkileri ile QT mesafesinde uzamaya ve TdP'ye neden olabilirler [6]. Mevcut kanıtlar QTc aralığının uzatılmasının florokinolonların sınıf etkisi olduğunu ancak bu grubun çeşitli üyeleri arasında geniş farklar olduğunu göstermektedir [11]. Halen piyasaya sürülen fluorokinolonlar dikkat çekici bir güvenlik profiline sahiptirler. Kinolonların izlem yapılmaksızın kullanımı büyük olasılıkla güvenilirdir ve proaritmi riski düşüktür [14-16]. Bununla birlikte, birkaç florokinolon (grepafloksasin ve son zamanlarda sparfloxacindahil) TP'nin belgelendirilmiş raporlarını takiben piyasadan çekilmiştir. Yapılan araştırmalarda moksifloksasin standart oral veya intravenöz dozda sırasıyla 6'ya 12 ms'likQTc uzamasına neden olmuştur[8]. 1111 hastadan elde edilen FDA verilerine göre, bu QT uzaması, klaritromisin ile kar-

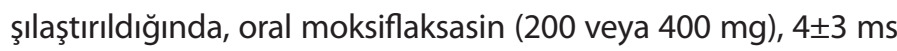
ve $5 \pm 12$ ms ile en az iki kat daha fazladır, $2 \pm 12$. [9]. Yeni bir klinik araştırmada, sağlıklı gönüllülere tek doz(1,5 kat) moksifloksasin, levofloksasin ve siprofloksasin ( 4 ms) ile karşılaştırıldığında QTc aralığının (yaklaşık 17 ms) dört misli uzamasına neden oldu [10]. Bizim hastamızda uzun QT sendromuna neden olabilecek moksifloksasin kullanımı dışında durum mevcut değildi. Hastamızda diyabetik ayak enfeksiyonu nedeni ile verilen moksifloksasinin ilk ve tek intravenöz 400mg doz sonrasında bazal EKG de 433msn ile sınırda olan QTc mesafesinde 63msn uzama meydana gelerek QTc mesafesi496msn olmuştur. Sonrasında kardiyak arreste neden olmuştur. Bu sendromun ortaya çıkması önceden öngörülememekle birlikte ilaç kullanımı sonrası ortaya çıkabilen uzun QT sendromunu önceden gösterebilecek bir parametre yoktur. Bununlabirlikte yine de nadir ancak önemli bukomplikasyon akıldan çıkarılmamalıdır.

Kronik iskemik kalp hastalığı ve korunmuş sol ventrikül fonksiyonu olan hastalarda, tüm kinolonlar EKG izlemesi yapılmaksızın kullanılabilir. Uzun QT sendromu vakalarında veya QT uzamaya eğilimli koşullara sahip hastalarda özel dikkat gösterilmelidir. Konjestif kalp yetmezliği, bradikardi, hipokalemi veya hipomagnezemi varlığında ve Sınıf la ve Sınıf III antiaritmik ajanlar gibi bağımsız olarak QTc aralığını uzatan ilaçların kullanılması durumunda, tedavinin başlangıcında kinolon tedavisi EKG monitörizasyonu ile tercih edilmelidir.

\section{Maddi Destek ve Çıkar İlişkisi}

Çalışmayı maddi olarak destekleyen kişi/kuruluş yoktur ve yazarların çıkara dayalı bir ilişkisi yoktur.

\section{Kaynaklar}

1. Moss AJ. Long QT syndrome. JAMA 2003; 289: 2041-44.

2. Vincet GM. Themoleculargenetic of thelong QT syndrome: Genes causing fainting and sudden death. Annu Rev Med 1998; 49: 263-74.

3. Vincent GM. Long QT syndrome. Cardiology Clinics 2000; 18: 309-25.

4. Roden DM. Takingthe 'idio' out of 'idiosyncratic'. Predicting torsades de pointes. Pacing Clin Electrophysiol 1998; 21: 1029-34.

5. Donger $\mathrm{C}$, Denjoy I, Berthet $\mathrm{M}$ et al. KVLQT1 $\mathrm{C}$ terminal missense mutation causes a forme fruste long QT syndrome. Circulation 1997; 96: 2778-81.

6. Wang WX, Ebert SN, Liu XK et al. "Conventional" antihistamines slow cardiac repolarization in isolated perfused (Langendorff) feline hearts. J Cardiovasc Pharmacol 1998; 32: 123-28.

7. Reardon M, Malik M. QT interval change with age in an overtly healthy older population. Clin Cardiol1996; 19: 94952.

8. Fogarty C, Grossman C, Williams J et al. Efficacy and safety of moxifloxacin vs. clarithromycin for community-acquiredpneumonia. Infect Med 1999; 16: 748 - 63.

9. Korvick J. QT and quinolones: recent regulatory actions. Office of Drug Evaluation IV. Division of Special Pathogens FDA 5/23/01.

10. Noel GJ, Natarajan J, Chien S et al. Effects of three fluoroquinolones on QT interval in healthy adults after single doses. Clin Pharmacol Ther 2003; 73: 292 - 303.

11. Stahlmann R, Schwabe R. Safetyprofile of grepafloxacin compared with other fluoroquinolones. J Antimicrob Chemother 1997; 40: $83-92$.

12. Owens RC Jr, Ambrose PG. Clinical use of the fluoroquinolones. Med Clin North Am 2000; 84: 1447 - 96.

13. Appelbaum PC, Hunter PA. The fluoroquinolone antibacterials: Past, present and future perspectives. Int J Antimicrob Agents 2000; $16: 5-15$.

14. Stahlman R, Lode H. Toxicity of quinolones. Drugs 1999; 58: 37 - 42 .

15. Bertino J, Fish D The safety profile of the fluoroquinolones Clin Ther 2000; 22: $798-817$.

16. Ball P. Future of the quinolones. Semin Respir Infect 2001; 16: $215-24$ 